\title{
Adverse Events of Bevacizumab in Patients with Metastatic Colorectal Cancer
}

\author{
ANDREEA-DANIELA GHEORGHE ${ }^{1,2}$, DANIELA ZOB ${ }^{3 *}$, DANA-LUCIA STANCULEANU ${ }^{3,4}$ \\ ${ }^{1}$ St. "Apostle Andrew” Emergency Hospital of Constanta, Oncology Department, 145 Tomis Blvd., 900591, Constanta, \\ Romania \\ 2“"Ovidius” University of Constanta, Faculty of Medicine, 124 Mamaia Blvd., 900527, Constanta, Romania \\ ${ }^{3}$ Department of Medical Oncology I, "Prof. Dr. Alexandru Trestioreanu" Institute of Oncology, 252 Fundeni Str., \\ Bucharest, Romania \\ 4“Carol Davila” University of Medicine and Pharmacy, 37 Dionisie Lupu Str., Bucharest, Romania
}

\begin{abstract}
Even with the decreasing incidence of colorectal cancer (CRC), data showing that the rate of incidence of CRC is declining with 2.9\% every year starting with 2005 until 2014, CRC remains one of the most frequent neoplasia all over the world. Almost a quarter of patients with CRC present with stage IV disease at diagnosis and nearly $30 \%$ of patients with localized disease will progress within 5 years. Our study included 129 patients with metastatic CRC that received chemotherapy \pm bevacizumab, from January 2017 until December 2018. Patients received fluropirimidine-based chemotherapy plus or minus bevacizumab. No significant differences was registered between groups with respects of age, sex, tumor localization, chemotherapy regimen used. Also no significant difference was found in our groups regarding risk factors for bleeding and medical history. No remarkable differences were registered between the two groups regarding common adverse reactions to chemotherapy, with the exception of physical asthenia which was found in a greater proportion of patients that received bevacizumab in combination with chemotherapy. In our study most frequent adverse events related to bevacizumab were grade 1 or 2, only few adverse events were grade 3 or 4 and lead to discontinuation of bevacizumab treatment, and these were mainly thromboembolic events and bleeding.
\end{abstract}

Keywords: metastatic colorectal cancer, bevacizumab, chemotherapy, adverse events.

Despite the decreasing incidence of colorectal cancer (CRC), data showing that the incidence of CRC decreased with 2.9\% every year starting with 2005 until 2014, CRC remains one of the most frequent neoplasia all over the world. No matter the cause of occurrence and the risk factors involved in its pathogeny, [1-6] in terms of CRC mortality, we also assist to a decreasing mortality from 1990, actual mortality rates being $50 \%$ down from the highest registered mortality rates $[7,8]$.

All these improvements in the rates of incidence and mortality from CRC are the results of CRC screening and early stage diagnosis, and of course due to better treatment options [9-12].

Although, the incidence and mortality of CRC is decreasing in general population, retrospective analysis of SEER CRC registry showed that the incidence of CRC is increasing in young patients. By 2030 data available are predicting a $124 \%$ increase in the incidence of CRC in young populations, therefore specific treatment strategies are needed [13, 14].

Almost a quarter of patients with CRC present with stage IV disease at diagnosis, and nearly $30 \%$ of patients with localized disease will progress within 5 years [15].

In the majority of patients with metastatic CRC systemic therapy is mandatory, and this therapy consists of fluropirimidine based chemotherapy and targeted therapies. Targeted therapies consist of biological agents targeting vascular endothelial growth factor (VEGF) used in unselected patients, and epidermal growth factor receptor (EGFR) in patients with RAS-wild type tumours [16].

FOLFOX and FOLFIRI regimens are comparable in terms of efficacy, the differences between these two regimens are related to toxicity. Bevacizumab (Avastin), a recombinant humanized monoclonal antibody directed against VEGF was approved in 2004 by Food and Drug Administration (FDA) in the treatment of metastatic CRC [17]. Multiple clinical trials are supporting currently guidelines that states the use of Bevacizumab in combination with chemotherapy as the standard option for patients with metastatic CRC, especially in patients with right sided tumors, either with RAS mutation or RAS wild type [18].

*email: danielazob@yahoo.com 
Bevacizumab showed important clinical benefits in patients with metastatic CRC, better progression free survival (PFS) and overall survival (OS), with well known specific adverse events like arterial hypertension, proteinuria, bleeding and thromboembolism [17,19]. Taking in consideration that clinical trials population are well selected, it is important to evaluate the adverse events that can occur in patients that are not included in clinical trials.

\section{Experimental part}

Our study included 129 patients with unresectable metatstatic CRC that received chemotherapy \pm bevacizumab, from January 2017 until December 2018. The study was conducted in Oncology Department of Clinical Emergency County Hospital of Constanta and in Department of Medical Oncology I, "Prof. Dr. Alexandru Trestioreanu" Institute of Oncology. The study was conducted according to our local ethics committee and patients were informed and signed inform consent prior to inclusion in this evaluation. All informations about patients were obtain from medical records of the clinics.

Patients characteristics included: age, sex, Eastern Cooperative Oncology Group performance status (ECOG), relevant medical history, including bleeding history, arterial hypertension, cardiovascular disease, thromboembolism, proteinuria, oncologic disease history (stage, tumor pathology) [20-23].

Patients received fluropirimidine-based chemotherapy plus or minus bevacizumab. Chemotherapy regimens were oxaliplatin-based regimen (FOLFOX) or irinotecan-based (FOLFIRI). Treatment was administred until disease progression, unacceptable adverse events or patients refusal to continue treatment.

Evaluation of the patients was performed every visit, every 2 weeks according to schedule. Patients were evaluated by complete physical examination, hematology, chemistry, urine evaluation [24-28].

Evaluation of adverse events was performed according to Common Terminology Criteria for Adverse Events (CTCAE) version 4.0. Statistical analyses was performed using the Statistical Package for the Social Sciences version 20.0 software (SPSS).

\section{Results and discussions}

Total group of patients in our study comprise of 129 patients with unresectable metastatic CRC that received chemotherapy \pm bevacizumab. Patients were divided in two groups: group A - patients that received chemotherapy plus bevacizumab and group B - patients that received chemotherapy alone. Patient characteristics are described in Table 1.

Group A consists of 60 patients with metastatic CRC that received chemotherapy plus bevacizumab and second group consists of 69 patients that received chemotherapy alone. No significant differences was registered between groups regarding age, sex, tumor localization, chemotherapy regimen used and also no significant difference was found regarding risk factor for bleeding and medical history [24-28]. In the group of patients receiving chemotherapy alone, more patients were using non-steroidal anti-inflammatory and anticoagulant drugs, comparing with those in the group of bevacizumab.

Table 1

CLINICAL CHARACTERISTICS OF ALL PATIENTS

\begin{tabular}{|c|c|c|c|}
\hline Characteristics & Group A $(n=60)$ & Group B $(n=69)$ & p-value \\
\hline $\begin{array}{l}\text { Age (years) } \\
\text { Median } \\
\text { Range } \\
>75 \\
<75\end{array}$ & $\begin{array}{c}64 \\
34-76 \\
7(11.66 \%) \\
53(88.33 \%)\end{array}$ & $\begin{array}{c}66 \\
40-78 \\
10(14.49 \%) \\
59(85.5)\end{array}$ & $\begin{array}{l}>0.05 \\
>0.05\end{array}$ \\
\hline $\begin{array}{c}\text { Sex } \\
\text { Female } \\
\text { Male } \\
\end{array}$ & $\begin{array}{l}28(46.66 \%) \\
32(53.33 \%)\end{array}$ & $\begin{array}{l}31(44.92 \%) \\
38(55.07 \%)\end{array}$ & $>0.05$ \\
\hline $\begin{array}{c}\text { Tumor localization } \\
\text { Colon } \\
\text { Rectum }\end{array}$ & $\begin{array}{l}45(75.0 \%) \\
15(25.0 \%)\end{array}$ & $\begin{array}{l}51(73.91 \%) \\
18(26.08 \%)\end{array}$ & $\mathrm{p}>0.05$ \\
\hline $\begin{array}{c}\text { Performance status } \\
0 \\
\text { I } \\
\text { II+ } \\
\end{array}$ & $\begin{array}{l}24(40.0 \%) \\
21(35.0 \%) \\
15(25.0 \%) \\
\end{array}$ & $\begin{array}{l}27(39.13 \%) \\
25(36.23 \%) \\
17(24.63 \%) \\
\end{array}$ & $\mathrm{p}>0.05$ \\
\hline $\begin{array}{c}\text { Site of metastasis } \\
\text { Liver } \\
\text { Lung } \\
\text { Others } \\
\end{array}$ & $\begin{array}{c}35(58.33 \%) \\
14(23.33) \\
11(18.33 \%) \\
\end{array}$ & $\begin{array}{l}39(56.52 \%) \\
17(24.63 \%) \\
13(18.84 \%) \\
\end{array}$ & $\mathrm{p}>0.05$ \\
\hline $\begin{array}{c}\text { Medical History } \\
\text { Arterial hypertension } \\
\text { Diabetes }\end{array}$ & $\begin{array}{l}11(18.33 \%) \\
19(90.62 \%)\end{array}$ & $\begin{array}{l}16(23.18 \%) \\
26(94.44 \%)\end{array}$ & $\mathrm{p}>0.05$ \\
\hline
\end{tabular}




\begin{tabular}{|c|c|c|c|}
\hline Peptic ulcer & 0 & $2(2.89 \%)$ & $13(18.84)$ \\
Cardiovascular disease \\
Proteinuria & $6(10.0 \%)$ & $9(13.04)$ & \\
\hline $\begin{array}{c}\text { Use of non-steroidal anti- } \\
\text { inflammatory and anticoagulant } \\
\text { therapy } \\
\text { Yes }\end{array}$ & $5(8.33 \%)$ & & $\mathrm{p}<0.05$ \\
No & $3(5.0 \%)$ & $56(81.15 \%)$ & \\
\hline Chemotherapy regimen & $57(95.0 \%)$ & & $\mathrm{p}>0.05$ \\
FOLFOX & $35(58.33 \%)$ & $41(59.52 \%)$ & \\
FOLFIRI & $25(41.66 \%)$ & $27(39.13 \%)$ & \\
\hline
\end{tabular}

${ }^{\mathrm{a}}$ Including atrial fibrillation, stroke, myocardial infarction, transient ischemic attack,peripheral arterial disease.

Adverse events related to chemotherapy, regardless of grade, observed in the two groups are described in Table 2, and there are no significant differences between the two groups regarding common adverse reactions to chemotherapy, with the exception of physical asthenia which was found in a greater proportion of patients that received bevacizumab in combination with chemotherapy.

Table 2

AVERSE EVENTS RELATED TO CHEMOTHERAPY

\begin{tabular}{|c|c|c|c|}
\hline $\begin{array}{c}\text { Adverse Event } \\
\text { (all grades) }\end{array}$ & $\begin{array}{c}\text { Group A } \\
\mathrm{n}=60\end{array}$ & $\begin{array}{c}\text { Group B } \\
\mathrm{n}=69\end{array}$ & P value \\
\hline Neutropenia & $34(56.66 \%)$ & $40(57.97 \%)$ & $\mathrm{p}>0.05$ \\
\hline Anemia & $8(13.33 \%)$ & $11(15.94 \%)$ & $\mathrm{p}>0.05$ \\
\hline Trombocytopenia & $16(26.66 \%)$ & $19(27.53 \%)$ & $\mathrm{p}>0.05$ \\
\hline Diarrhea & $12(20.0 \%)$ & $13(18.84 \%)$ & $\mathrm{p}>0.05$ \\
\hline Vomiting & $23(38.33 \%)$ & $27(39.13 \%)$ & $\mathrm{p}>0.05$ \\
\hline Nausea & $32(53.33 \%)$ & $39(56.52 \%)$ & $\mathrm{p}>0.05$ \\
\hline Physical asthenia & $25(41.66 \%)$ & $19(27.53 \%)$ & $\mathrm{P}<0.05$ \\
\hline
\end{tabular}

Regarding severe adverse reactions related to chemotherapy regimen, we found a high incidence of neutropenia in both groups, but without significant differences. Febrile neutropenia was found more frequent in chemotherapy alone group, and thrombocytopenia was found more frequent in bevacizumab group. Grade 3 physical asthenia was observed in 6 patients receiving chemotherapy plus bevacizumab, comparing with only 2 patients in chemotherapy alone group.

Table 3

GRADE 3 AND 4 ADVERSE EVENTS RELATED TO CHEMOTHERAPY

\begin{tabular}{|l|l|l|l|}
\hline $\begin{array}{l}\text { Adverse Event } \\
\text { Grade } \geq 3\end{array}$ & $\begin{array}{l}\text { Group A } \\
\mathrm{n}=60\end{array}$ & $\begin{array}{l}\text { Group B } \\
\mathrm{n}=69\end{array}$ & $\mathrm{P}$ value \\
\hline Neutropenia & $21(35.0 \%)$ & $26(37.68 \%)$ & $\mathrm{p}>0.05$ \\
\hline Anemia & $2(3.33 \%)$ & $3(4.34 \%)$ & $\mathrm{p}>0.05$ \\
\hline Trombocytopenia & $4(6.66 \%)$ & $1(1.44 \%)$ & $\mathrm{p}<0.05$ \\
\hline Diarrhea & $5(8.33 \%)$ & $4(5.72 \%)$ & $\mathrm{p}>0.05$ \\
\hline Vomiting & $2(3.33 \%)$ & $2(2.89 \%)$ & $\mathrm{p}>0.05$ \\
\hline Nausea & $4(6.66 \%)$ & $3(4.34 \%)$ & $\mathrm{p}>0.05$ \\
\hline Physical asthenia & $6(10.0 \%)$ & $2(2.89 \%)$ & $\mathrm{p}<0.05$ \\
\hline
\end{tabular}

Toxicities associated with bevacizumab are described in Table 4. The most frequent adverse events were hypertension, proteinuria and bleeding.

Table 4

BEVACIZUMAB RELATED ADVERSE EVENTS

\begin{tabular}{|c|c|}
\hline Adverse Event (all grades) & $\begin{array}{c}\text { Group A } \\
\mathrm{n}=60\end{array}$ \\
\hline Bleeding & $4(6.66 \%)$ \\
Hemoptisis & $6(10.0 \%)$ \\
Epistaxis & $3(5.0 \%)$ \\
\hline Digestive bleeding & $13(21.66)$ \\
\hline Hypertension & $3(5.0 \%)$ \\
\hline Thromboembolic event & $20(33.33 \%)$ \\
\hline Proteinuria & \\
\hline
\end{tabular}


Multiple clinical trials data proved that Bevacizumab is associated with benefits in the treatment of patients with metastatic CRC. Chemotherapy choice in combination with bevacizumab depends on patients medical history and comorbidities, toxicities, convenience. Most data support the use of FOLFOX and FOLFIRI [24-28].

In the present study we analyzed adverse events related to bevacizumab in patients with metastatic CRC in clinical setting.

In our study most frequent adverse events related to bevacizumab were grade 1 or 2 , only few adverse events were grade 3 or 4 and lead to discontinuation of bevacizumab treatment, and these were mainly thromboembolic events and bleeding. Hypertension was observed in 13 patients, all patients had medical history of arterial hypertension and hypertension was properly controlled with medication prescribed by cardiologist. Thromboembolic events occurred in 3 cases and in all cases bevacizumab was discontinued; arterial thromboembolism was diagnosed on CT scan, patients being asymptomatic. Digestive bleeding was also observed in 3 patients receiving bevacizumb and chemotherapy, and bleeding was related to duodenal or gastric ulcer.

\section{Conclusions}

Adverse events related to Bevacizumab in our study, were similar to other clinical trials, with the exception that our study revealed slightly increased incidence of thromboembolic events. Bevacizumab related adverse events are usually mild or moderate and easy to manage. It is important to evaluate the patients medical history and risk factors. Monitoring blood pressure and proteinuria, both very important risk factors for cardiac and renal events, at every visit is mandatory in order to manage the most frequent adverse events related to Bevacizumab, to prevent treatment discontinuation, and improve the outcome of metastatic CRC patients.

\section{References}

1.INOUE, M., IWASAKI, M., OTANI, T., et al., Arch. Intern. Med., 166, 2006, p.1871

2.COZARU, G., SUCEVEANU, AI., VOINEA, F., ARS Medica Tomitana, 3, no. 50, 2007, p. 47-53.

3.YAMADA, A., KOMAKI, Y., KOMAKI, F., et al.,. Lancet, 19, 2008,p.758.

4.TOFOLEAN, D.E., MAZILU, L., STANICEANU, F., MOCANU, L., SUCEVEANU, BAZ, R., PAREPA, R.I., SUCEVEANU, A.P., BONDARI, S., BONDARI, D., VOINEA, F., Romanian Journal of Morphology and Embriology, 56, no. 3, 2015, p. $1205-1210$.

5.OH, M., MCBRIDE, A., YUN, S., et al., J Natl Cancer Inst, 110, 2018, p.1178.

6.SUCEVEANU, A.I., MAZILU, L., SUCEVEANU, A.P., Colorectal Cancer - Surgery, Diagnostics and Treatment, ISBN 978-953-51-1231-0, 2014, p. 403-433

7.SIEGEL, R.L., MILLER, K.D., JEMAL, A., CA Cancer J Clin, 68, 2018, no.1, p.7-30.

8.CHENG, L., ENG, C., NIEMAN, L.Z., at al.Am J Clin Oncol, 34, 2011, p. 573-580.

9.SUCEVEANU, A.I., SUCEVEANU, A.P., VOINEA, F.,, MAZILU, L., MIXICI, F., ADAM, T. Journal of Gastrointestinal and Liver Diseases (JGLD), An International Journal of Gastroenterology and Hepatology, 2009, 18 ,no.1, p. 33-38.

10.WEINBERG, BA., MARSHALL, JL., SALEM, ME. Williston Park, 31, 2017, p. 381-389. https://www.ncbi.nlm.nih.gov/pubmed/28516436 11.BOlOCAN, A., PADURARU, D.A., NITIPIR, C., HAINAROSIE, R., SILIU, M.P., DIACONU, C., SUCEVEANU, A.P., STOIAN, A.P., Romanian Biotechnological Letters, 23, no. 6, 2018, p. 14193- 14203.

12.MAZILU, L., CIUFU, N., GALAN, M., SUCEVEANU, A.I., SUCEVEANU, A.P., PAREPA, I.R., TOFOLEAN, D.E., Chirurgia (Bucharest), 107, no. 1, 2012, p. 55-58.

14.BAILEY, C.E., HU, C.Y., YOU, Y.N., et al. JAMA Surg., A4, 2010, p. 1-6.

15.SUCEVEANU, A.I., STOIAN, A.P., PAREPA, I.R., VOINEA, C., HAINAROSIE, R., MANUC, D., NITIPIR, C., MAZILU, L., SUCEVEANU, A.P., Rev. Chim. (Bucharest), 69, no. 8, 2018, p. 2260-2267.

16.SHAH, M.A., RENFRO, L.A., ALlEGRA, C.J., ANDRE, T., DE GRAMONT, A., SCHMOLL, H.J. et al. J Clin Oncol, 34, 2016, p. 843853.

17.VAN CUTSEM, E., CERVANTES, A., ADAM, R., SOBRERO, A., VAN KRIEKEN, J.H., ADERKA, D. et al. Ann Oncol., 2016, p. 1-38.

17.HURWITZ, H., FEHRENBACHER, L., NOVOTNY, W., et al. N Engl J Med., 350,no.23, 2004, p. 2335-2342.

18.BARANISKIN, A., BUCHBERGER, B., POX, C., GRAEVEN, U., HOLCH, J.W., SCHMIEGEL, W., HEINEMANN, V. European Journal of Cancer, 106, 2019, pp 37-44

19.SALTZ LB, CLARKE S, DÍAZ,RUBIO E, SCHEITHAUER W, FIGER A, WONG R, KOSKI S,

LICHINITSER M, YANG TS, RIVERA F, COUTURE F, SIRZÉN F, CASSIDY J. J Clin Oncol, 26, 2008, p.2013-2019.

20.PANTEA STOIAN, A., BALA, C., RUSU, A., et al., Rev. Chim. (Bucharest), 69, no.4, 2018, p.864-869.

21.TULIN, A.,SLAVU, I., TULIN, R., et al. Journal Of Mind And Medical Sciences, 5, no.1, 2018, p.101-108.

22.BOLOCAN, A., PADURARU, D.N., NITIPIR, C., et al. Romanian Biotechnological Letters, 23, no. 6, 2018, p.14193-14202.

23.NITIPIR, C., BARBU, MA., ORLOV, C.,et al. Romanian Biotechnological Letters, 24, no. 1, 2019, p.40-146.

24.CIOCIRLAN, M.,DRAGHIA, L., MANUC, D., et al. Conference: 3rd International Conference on Interdisciplinary Management of Diabetes Mellitus and its Complications (INTERDIAB) Location: Bucharest, ROMANIA Date: MAR 02-04, 2017; SANOFI INTERDIAB 2017: DIABETES MELLITUS IN INTERNAL MEDICINE Book Series: International Conference on Interdisciplinary Management of Diabetes Mellitus and its Complications, 2017, p.132-138.

25.CIUHU, A.N, PANTEA-STOIAN, A.M., NITIPIR, C., et al. Conference: 3rd International Conference on Interdisciplinary Management of Diabetes Mellitus and its Complications (INTERDIAB)Location: Bucharest, ROMANIA Date: MAR 02-04, 2017; SANOFI NTERDIAB 2017: DIABETES MELLITUS IN INTERNAL MEDICINE Book Series: International Conference on Interdisciplinary Management of Diabetes Mellitus and its Complications, 2017, p.139-147. 
26.NITIPIR, C., DIACONU, C.C., ORLOV, .C; et al. Conference: 35th Balkan Medical Week on Healthy Ageing - An Endless Challenge Location: Athens, GREECE Date: SEP 25-27, 2018 PROCEEDINGS OF THE 35TH BALKAN MEDICAL WEEK ,2018,p.133-137.

27.PANTEA STOIAN, A., BALA, C., RUSU, A.,et al. Rev. Chim. (Bucharest), 69, no.4, 2018,p.864-869.

28.PANTEA STOIAN, A.,ELIAN, V.,NITIPIR, C., et al. Conference: 3rd International Conference on Interdisciplinary Management of Diabetes Mellitus and its Complications (INTERDIAB)Location: Bucharest, ROMANIA Date: MAR 02-04, 2017; SANOFI INTERDIAB 2017:

DIABETES MELLITUS IN INTERNAL MEDICINE Book Series: International Conference on Interdisciplinary Management of Diabetes Mellitus and its Complications, 2017, p. 232-242

Manuscript received: 4.09 .2019 